\title{
Enzymatic mechanism of human apurinic/apyrimidinic endonuclease against a THF AP site model substrate ${ }^{\dagger}$
}

\author{
Sophia T. Mundle ${ }^{\ddagger}$, James C. Delaney§, John M. Essigmann $\S, \dagger$, and Phyllis R. Strauss $\ddagger, \dagger,{ }^{*}$ \\ *Department of Biology, Northeastern University, Boston, MA 02115 \\ $\S$ Departments of Biological Engineering and Chemistry, Massachusetts Institute of Technology, \\ Cambridge, MA 02139
}

\section{Abstract}

The endonucleolytic activity of human apurinic/apyrimidinic endonuclease (AP endo) is a major factor in the maintenance of the integrity of the human genome. There are estimates that this enzyme is responsible for eliminating as many as $10^{5}$ potentially mutagenic and genotoxic lesions from the genome of each cell every day. Furthermore, inhibition of AP endonuclease may be effective in decreasing the dose requirements of chemotherapeutics used in the treatment of cancer as well as other diseases. Therefore, it is essential to accurately and directly characterize the enzymatic mechanism of AP endo. Here we describe specifically designed double stranded DNA oligomers containing tetrahydrofuran (THF) with a 5' phosphorothioate linkage as the abasic site substrate. Using $\mathrm{H}_{2}{ }^{18} \mathrm{O}$ during the cleavage reaction and leveraging the stereochemical preferences of AP endo and T4 DNA ligase for phosphorothioate substrates, we show that AP endo acts by a one-step associative phosphoryl transfer mechanism on a THF-containing substrate.

Human apurinic/apyrimidinic endonuclease (AP endo, HAP1, Apex, Ref1) is a DNA base excision repair enzyme with a wide variety of functions, including AP endonuclease (cleaving an AP site 5' to a deoxyribose phosphate (dRP) moiety), 3' exonuclease, 3' phosphodiesterase, 3' phosphatase, $\mathrm{RNaseH}$ and 5' endonuclease activities (reviewed in $(1,2)$ ). The characterization of the human enzyme occurred several years after the Escherichia coli functional homolog (ExoIII) was found to have AP endonuclease activity (3-10). In addition to the wide variety of functions, mammalian $\mathrm{AP}$ endo has been shown to act on many types of DNA substrate molecules, but demonstrates the most robust activity when acting as a Class II AP endonuclease. The turnover number for 5' cleavage of a reduced AP site is $10 \mathrm{~s}^{-1}(11)$, even faster than the highly effective DNA repair enzyme uracil DNA glycosylase (UDG), which has a turnover number for uracil excision of $5 \mathrm{~s}^{-1}(12)$.

A variety of AP site analogs have been tested to probe the 5'AP site nicking activity of AP endo (11,13-15). Of particular interest here is that replacement of a nonbridging phosphorous oxygen 5' to the AP site with sulfur has major consequences on enzymatic activity. In 1995, Wilson et al. showed that incision activity on the $S_{\mathrm{p}}$ isomer of a phosphorothioate by the human AP endo is 10,000-fold reduced, while incision on the $R_{\mathrm{p}}$ isomer is only 20 -fold reduced (14). Therefore, in a mixture of $S_{\mathrm{p}}$ and $R_{\mathrm{p}}$ stereoisomers of AP endo substrate, the enzyme will have a vast preference for cleavage of the $R_{\mathrm{p}}$ stereoisomer.

\footnotetext{
${ }^{\dagger}$ Supported by National Institutes of Health Grant CA 72702 (to P.R.S.), and NIH Grant CA80024 and NIEHS Grant P30 ES002109 (to J.M.E.)

*To whom correspondence should be addressed. Tel. (617) 373-3492; fax (617) 373-2138; email p.strauss@neu.edu.
} 
We recently proposed a two-step enzymatic mechanism in which Tyr ${ }^{171}$ acts directly as the attacking nucleophile (16). One way to evaluate this proposal involves use of substrate DNA containing a phosphorothioate linkage. Phosphorothioate RNA and DNA have been used in a wide variety of applications (reviewed by Summerton (17)), including RNA-mediated interference (RNAi) (18) and as drugs targeted towards specific pathogenic proteins, as in the case of the malarial topoisomerase II (19). By far, the most specific use of phosphorothioate oligonucleotides has been in the investigation of the stereochemical course of enzymatic reactions (20-23).

DNA cleavage reactions performed on phosphorothioate DNA in the presence of $\mathrm{H}_{2}{ }^{18} \mathrm{O}$ generate product DNA with a 5' terminal chiral thiophosphate (21). The chirality of the product DNA is dependent on both the stereochemistry of the starting material $\left(S_{\mathrm{p}}\right.$ or $\left.R_{\mathrm{p}}\right)$ and the nature of the enzymatic reaction (one-step with inversion of configuration of the scissile phosphate or two-step, which occurs with no net inversion of configuration). Product DNA generated in this manner can then be configurationally defined using the well-documented stereochemistry of the T4 DNA ligase reaction, through which the proR oxygen from the 5' terminal thiophosphate donor is always lost to AMP during the course of the ligase reaction (21) (Figure 1). Knowing that T4 DNA ligase is able to ligate DNA efficiently when a 5' dRP group is present at the terminus of the donor DNA (24) enabled us to follow the fate of ${ }^{18} \mathrm{O}$ after AP endo cleavage of the $R_{\mathrm{p}}$ stereoisomer of substrate DNA, and subsequent ligation of the product DNA with a partner oligonucleotide. We could thus discriminate between a one-step (Figure 1A) and a two-step (Figure 1B) hydrolytic mechanism.

\section{EXPERIMENTAL PROCEDURES}

Three oligonucleotides were designed such that the AP endo reaction site/ligation site was flanked by HaeIII restriction sites (underlined). The tetrahydrofuran AP site analog containing a 5 ' phosphorothioate linkage is represented by $\mathrm{sF}$, while the analogous phosphodiester control is abbreviated as $\mathrm{pF}$ :
STM5
5'-CCATGCCTGCACGAsFTGGCCGAATTCTTC-3'
STM6
5'-GAAGAATTCGGCCAGTCGTGCAGGCATGG-3'
STM7
5'-GAAGAATTCGGCCAGAGGCCAAGAGCGCGCTTTTGCGCGCTCTTGGCCT-3'

The above oligomers were synthesized Trityl-OFF by GeneLink (Hawthorne, NY). The DNA oligonucleotide STM5 was generated by automated DNA synthesis (Expedite 8909 DNA Synthesizer, PerSeptive Biosystems, Inc., Framingham, MA) and standard phosphoramidite chemistry. The phosphorothioate linkage was introduced using the Beaucage (25) sulfurizing reagent (3H-1,2-benzodithiol-3-one 1,1-dioxide) (Glen Research, Sterling, VA), which yields $\sim 96 \%$ phosphorothioate linkages. The stable AP site (THF, F) was introduced to the DNA oligomer using dSpacer CE phosphoramidite (5'-O-Dimethoxytrityl-1',2'-Dideoxyribose-3'[(2-cyanoethyl)- (N,N-diisopropyl)]-phosphoramidite) (Glen Research, Sterling, VA).

Attempts to resolve the $S_{\mathrm{p}}$ and $R_{\mathrm{p}}$ diastereomers by HPLC using reversed phase columns and the many conditions described by Subach et al.(26) for our sequences were unsuccessful.

Therefore, the AP endo reaction was performed on a mixture of diastereomers. DNA samples were PAGE-purified from an $18 \%$ preparative gel. All oligomers were greater than $95 \%$ pure as determined by $5^{\prime}\left[{ }^{32} \mathrm{P}\right]$ end-labeling with polynucleotide kinase (New England Biolabs, Beverly, MA), resolution on an 18\% denaturing polyacrylamide gel, and PhosphorImager analysis. After PAGE purification, desalted oligomers were dissolved either in sterile $\mathrm{H}_{2} \mathrm{O}$ or sterile $\mathrm{H}_{2}{ }^{18} \mathrm{O}$ (Cambridge Isotope Laboratories, Inc., Cambridge, MA). The subsequent 
enzymatic reactions were performed either in $100 \% \mathrm{H}_{2} \mathrm{O}$ or $\mathrm{H}_{2}{ }^{18} \mathrm{O}$ (at $96 \%$ isotopic abundance).

The overall experimental scheme is depicted in Figure 2. The substrate for the AP endo reaction was generated by annealing STM5 and STM6 in equimolar quantities ( $4 \mu \mathrm{M}$ final DNA concentration). This was accomplished by heating the mixture to $70{ }^{\circ} \mathrm{C}$ and allowing it to cool slowly to room temperature in either $\mathrm{H}_{2} \mathrm{O}$ or $\mathrm{H}_{2}{ }^{18} \mathrm{O}$. The AP endo reaction, performed in 800 $\mu \mathrm{l}$ total volume, contained $750 \mathrm{nM}$ ds substrate DNA and $100 \mathrm{nM}$ AP endo in $50 \mathrm{mM}$ Hepes/ $\mathrm{NaOH}, \mathrm{pH} 7.5,0.1 \mathrm{mM}$ EDTA, $65 \mathrm{mM} \mathrm{NaCl}, 10 \%$ glycerol and $5 \mathrm{mM} \mathrm{MgCl}_{2}$. Initially, a time course ( $\left(0-3 \mathrm{~h}\right.$ ) was performed using a $5 \mu \mathrm{l}$ total reaction volume and [ $\left.{ }^{32} \mathrm{P}\right] 5^{5}$ ' end-labeled substrate DNA, which determined that $3 \mathrm{~h}$ was an appropriate end point for the reaction (Figure 3). Reactions were incubated for $3 \mathrm{~h}$ at $22{ }^{\circ} \mathrm{C}$, then terminated by addition of EDTA to 100 $\mathrm{mM}$. The reaction mixture was desalted using illustra ${ }^{\mathrm{TM}}$ MicroSpin $^{\mathrm{TM}} \mathrm{G}-25$ Columns (GE Healthcare, Buckinghamshire, UK), phenol extracted and ethanol precipitated in the presence of $0.3 \mathrm{M}$ sodium acetate. In order to ensure that ${ }^{18} \mathrm{O}$ was incorporated into the reaction product, a sample was analyzed by mass spectrometry as described in the Results.

Following processing of the AP endo reaction product, all subsequent steps were performed in sterile, non-isotopically enriched $\mathrm{H}_{2} \mathrm{O}$. Ligation reactions were performed in $100 \mu$ lotal volume. Eight thousand pmoles $(\approx 8$-fold molar ratio) STM7 hairpin DNA was mixed with the AP endo reaction product. The DNA mixture was heated to $70^{\circ} \mathrm{C}$ and slow-cooled to room temperature for annealing. The samples were then allowed to cool to $16^{\circ} \mathrm{C}$ for $5 \mathrm{~min}$ before adding T4 DNA ligase buffer (ATP included) to and 60 units of T4 DNA ligase (Promega Corp., Madison, WI). After ligation reactions were incubated for $2 \mathrm{~h}$ at $16^{\circ} \mathrm{C}$, an additional 60 units T4 DNA ligase and $50 \mathrm{nmol}$ fresh ATP were added. Ligation reactions were allowed to proceed overnight at $16{ }^{\circ} \mathrm{C}$. The T4 DNA ligase reaction product was processed by G-25 desalting. The sample was then digested with 80 units HaeIII (New England Biolabs, Beverly, MA) in $120-130 \mu 11 \times$ NE Buffer 2 for $2-4$ hours at $37^{\circ} \mathrm{C}$ followed by heat inactivation of the enzyme at $80^{\circ} \mathrm{C}$ for $20 \mathrm{~min}$. Analysis of $100 \mu \mathrm{l}$ of the HaeIII product was then performed by electrospray ionization time of flight mass spectrometry (ESI-TOF MS) by means of an Agilent 1100 MSD ESI-TOF calibrated with a commercial tuning mixture just prior to analysis (as in the Supplementary Methods of Delaney et al (27) with some minor modifications to the HPLC method).

ESI-TOF MS afforded the extreme sensitivity and isotopic resolution required to differentiate between ${ }^{16} \mathrm{O}$ and ${ }^{18} \mathrm{O}$ in a $7 \mathrm{mer}$ single-stranded DNA molecule. Mass accuracy and resolution were typically less than 1 p.p.m. and higher than 10,000, respectively. The parameters used were as follows: Capillary voltage was $-3500 \mathrm{~V}$, nebulizing gas pressure was $35 \mathrm{psi}$ and drying gas flow was $12 \mathrm{l} / \mathrm{min}$ at $325^{\circ} \mathrm{C}$. The fragmentor was set at $225 \mathrm{~V}$ and scans were taken from $100-2000 \mathrm{~m} / \mathrm{z}$. The injection needle was washed $2 \times$ in $100 \%$ methanol prior to sample injection onto the column. An Agilent 1100 Series thermostatted autosampler in series with a reverse phase column (Agilent Zorbax SB-Aq; $3.5 \mu \mathrm{m} ; 2.1 \mathrm{~mm} \times 150 \mathrm{~mm}$ ) was used to introduce the sample at $0.3 \mathrm{ml} / \mathrm{min}$, using a gradient of $0 \%-50 \%$ B over 20 min followed by $50 \%-80 \% \mathrm{~B}$ over $5 \mathrm{~min}$, and equilibration of 0\%-0\% B for $12 \mathrm{~min}$ (A: $10 \mathrm{mM}$ ammonium acetate; B: $100 \%$ acetonitrile). Time of entry into the mass spectrometer for the 15 mer AP endo product was 9.4 $\mathrm{min}$, and for the $7 \mathrm{mer}$ AP endo-ligated/HaeIII product was $8.1 \mathrm{~min}$. The expected monoisotopic values for the most populated charge states of a given single-stranded DNA fragment of interest were used to extract the ions from the total ion chromatograph; a range of $4 \mathrm{~m} / \mathrm{z}$ centered about the expected ${ }^{16} \mathrm{O}$ monoisotopic value was used, ensuring representation of both ${ }^{16} \mathrm{O}$ and ${ }^{18} \mathrm{O}$ species. Background was subtracted from the appropriate extracted ion peak, taking juxtaposed regions of identical width from both sides. 


\section{RESULTS}

Initial experiments were performed in order to determine suitable conditions for the AP endo reaction. After varying the concentration of the enzyme and the amount of time that the reaction was allowed to proceed, we determined that at $750 \mathrm{nM}$ substrate and $100 \mathrm{nM}$ enzyme, a reaction time of $3 \mathrm{~h}$ was sufficient to convert most, if not all, of the $R_{\mathrm{p}}$ substrate DNA into product. Figure 3 represents the time course of the AP endo reaction. By three hours the rate of reaction had tapered off, and the amount of product was $\sim 50 \%$ of the substrate. This result indicated that the reaction had gone to completion and that cleavage of the $S_{\mathrm{p}}$ diastereomer was minimal. Confirmation of the report that AP endo cleaves the $R_{\mathrm{p}}$ stereoisomer (14) was obtained by digestion of the AP endo reaction product with either nuclease P1 (which cleaves the $S_{\mathrm{p}}$ stereoisomer and not the $R_{\mathrm{p}}$ ) or snake venom phosphodiesterase (which cleaves the $R_{\mathrm{p}}$ stereoisomer and not the $S_{\mathrm{p}}$ ). Analysis of these products by ESI-TOF mass spectrometry confirmed that the DNA refractory to cleavage by AP endo was also resistant to cleavage by snake venom phosphodiesterase but sensitive to cleavage by nuclease P1, as predicted (see supplemental information).

The T4 DNA ligase reaction was optimized using $\left[{ }^{32} \mathrm{P}\right]$ end-labeled substrate DNA. The ratio of AP endo reaction product to STM7 49mer hairpin oligomers was varied. Product formation was maximal with an 8:1 ratio of STM7 acceptor to 5' thiophosphate donor DNA and by addition of extra ATP $(0.5 \mathrm{mM})$ and ligase (60 units) mid-reaction, as described by Carey et al.(28). Although only 1-3\% ligation occurred (data not shown), the quantity of product (80$240 \mathrm{pmol}$ ) was sufficient for detection by ESI-TOF MS. Consequently, the reaction was scaled up and performed without the radiolabel (see below). The experiment was designed to eliminate the need for purification of oligonucleotide fragments after each enzymatic step, which would have been an arduous task. As judged by mass spectrometry of the AP endo product and its ligation/HaeIII product, the 29 mer starting material contained $\sim 5 \%$ of a 5 ' phosphodiesterTHF $(\mathrm{pF})$ linkage (16 amu less than the expected phosphorothioate product, data not shown). This outcome could be possible due to incomplete sulfurization or desulfurization during solidphase chemical synthesis $(29,30)$, and the difficulty of purifying a large DNA molecule. Since the ligation efficiency of the AP endo cleavage product was low (1-3\%), one may be concerned that most of the ligated material would be from the $\mathrm{pF}$ contaminant, which would presumably ligate more efficiently. This possibility was not the case, as there was $\sim 5 \%$ of $\mathrm{pF}$ signal for both the 15mer AP endo product and the 7mer ligation/HaeIII product. Nevertheless, the small $\mathrm{pF}$ contaminant did not adversely affect the mass spectral interpretation, since our analysis focused on molecules that contained the phosphorothioate linkage, and ligation of the AP endo product to a dissimilar oligonucleotide ensured that the observed events occurred from a successful AP endo event (allowing ${ }^{18} \mathrm{O}$ incorporation), followed by a successful T4 DNA ligase event.

In order to determine whether the modified conditions for ESI-TOF MS used by Delaney et al.(27) were appropriate for this DNA sample, we analyzed the AP endo reaction product prior to ligation. The expected molecular formula for the neutral $15 \mathrm{mer}$ AP endo reaction product bearing the 5 ' $\mathrm{sF}$ group in $\mathrm{H}_{2} \mathrm{O}$ is $\mathrm{C}_{141} \mathrm{H}_{184} \mathrm{~N}_{47} \mathrm{O}_{92} \mathrm{P}_{15} \mathrm{~S}_{1}$, which has a theoretical monoisotopic $\left(100 \%{ }^{12} \mathrm{C}\right)$ mass to charge ratio $(\mathrm{m} / \mathrm{z})$ of 1124.916 in the -4 charge state. After analysis of the sample and extraction of ions $1123-1127 \mathrm{~m} / \mathrm{z}$, a characteristic mass spectrum for DNA of the appropriate size (1124.919) was obtained (Figure 4A). Despite ion extraction, signal for the -3 charge state $(\mathrm{m} / \mathrm{z}$ of 1500.224$)$ was poorly resolved, and that for the -5 charge state $(\mathrm{m} /$ $\mathrm{z}$ of 899.731) was not detected (data not shown). The Molecular Weight Calculator version 6.45, written by Matthew Monroe for the Department of Energy (under grant RR018522 and contract DE-AC05-76RL0 1830, PNNL, Richland, WA) revealed that the theoretical isotopic distribution (Figure $4 \mathrm{~A}$, inset) agreed well with what was observed. The signal for the -4 charge state was strong enough to rationalize performing the large scale reaction with unlabeled 
substrate in $\mathrm{H}_{2}{ }^{18} \mathrm{O}$ for analysis of products. In $\mathrm{H}_{2}{ }^{18} \mathrm{O}$, the expected molecular formula for the neutral product DNA is $\mathrm{C}_{141} \mathrm{H}_{184} \mathrm{~N}_{47} \mathrm{O}_{91} \mathrm{P}_{15} \mathrm{~S}_{1}+{ }^{18} \mathrm{O}_{1}$, which has a theoretical $\mathrm{m} / \mathrm{z}$ ratio of 1125.417 in the -4 charge state. Upon extraction of 1123-1127 ions, a signal of 1125.421 was obtained (Figure 4B). Minor $(<15 \%)$ contamination with the ${ }^{16} \mathrm{O}$ product DNA was expected since there was $\sim 4-5 \% \mathrm{H}_{2} \mathrm{O}$ present during the reaction, which has no bearing on the analysis, as the complete retention vs. complete loss of ${ }^{18} \mathrm{O}$ signal is probed (and not ${ }^{18} \mathrm{O} /{ }^{16} \mathrm{O}$ ratios). These results served as proof of principal, in that we were able to demonstrate $\mathrm{H}_{2}{ }^{18} \mathrm{O}$ incorporation into the AP endo reaction product, and that the ${ }^{18} \mathrm{O}$ signal was abundant enough to discern its retention vs. loss.

The product of the AP endo reaction in $\mathrm{H}_{2} \mathrm{O}$, followed by ligation and HaeIII digestion, is expected to yield a 7 mer with a neutral molecular formula of $\mathrm{C}_{63} \mathrm{H}_{85} \mathrm{~N}_{20} \mathrm{O}_{43} \mathrm{P}_{7} \mathrm{~S}_{1}$ and monoisotopic $\mathrm{m} / \mathrm{z}$ ratios of 685.091 and 1028.140 in the respective -3 and -2 charge states. After extraction of ions from 683-687 and 1026-1030 m/z, we found close agreement of the theoretical with the observed $\mathrm{m} / \mathrm{z}$ values of 685.093 and 1028.143 (Figures $5 \mathrm{~A}$ and $5 \mathrm{~B}$ ). The Molecular Weight Calculator revealed that the theoretical isotopic distribution agreed well with what was observed for the -3 charge state (Figure 5A); the small increased deviation in the 1028.6 peak for the -2 charge state (Figure 5B) is most likely due to a species co-migrating on this rather steep LC gradient. In the case of a one step hydrolysis, the $\mathrm{m} / \mathrm{z}$ ratios of the AP endo reaction product performed in $\mathrm{H}_{2}{ }^{18} \mathrm{O}$, followed by ligation and $\mathrm{Hae}$ III digestion, were expected to be the same as when performed in $\mathrm{H}_{2} \mathrm{O}$ (Figures 5A and 5B). In the event of a two step hydrolysis ${ }^{18} \mathrm{O}$ incorporation would give a neutral molecular formula of $\mathrm{C}_{63} \mathrm{H}_{85} \mathrm{~N}_{20} \mathrm{O}_{42} \mathrm{P}_{7} \mathrm{~S}_{1}+{ }^{18} \mathrm{O}_{1}$ and expected $\mathrm{m} / \mathrm{z}$ ratios of 685.759 and 1029.142 for the respective -3 and -2 charge states. Figure $5 \mathrm{C}$ and $\mathrm{D}$ show that the $\mathrm{m} / \mathrm{z}$ ratios obtained after reaction in $\mathrm{H}_{2}{ }^{18} \mathrm{O}$ of 685.089 and 1028.141 for the respective -3 and -2 charge states correlated well with the values seen when the reaction was performed in $\mathrm{H}_{2} \mathrm{O}$, even though ${ }^{18} \mathrm{O}$ had clearly been incorporated into the starting material prior to ligation. Therefore, we conclude that AP endo cleaves a THF-containing substrate by a one-step mechanism.

\section{DISCUSSION}

Here, we describe experiments, using mass spectrometry, $\mathrm{H}_{2}{ }^{18} \mathrm{O}$, and the known stereochemical preferences of AP endo and T4 DNA ligase, to determine the enzymatic mechanism of human AP endo, a critical enzyme in maintaining the integrity of the human genome during normal metabolism as well as in times of oxidative stress. Phosphorothioatecontaining DNA oligomers are a powerful tool for studying the stereochemistry of DNA metabolizing enzymes involved in phosphoryl transfer reactions (reviewed in $(31,32)$ ). In particular, they have been used to determine the type of mechanism employed by a number of restriction endonucleases (21,22,33-39), vaccinia type 1 topoisomerase (23), DNA polymerase I Klenow fragment (40) and HIV-1 reverse transcriptase (41-43), among others.

Enzymes that cleave the phosphodiester backbone of DNA molecules generally act by one of two mechanisms, which differ in the identity of the nucleophile that carries out the attack. The most common mechanism is one in which activated water is the attacking nucleophile. In this one-step mechanism, a highly unstable pentacoordinate transition state is formed, resulting in cleavage of the scissile bond. Most Type II restriction endonucleases act by this type of mechanism (21,33-39). The less common two-step mechanism is one in which a nucleophile, provided by the enzyme, carries out direct attack of the scissile phosphate. In a two-step mechanism, nucleophilic attack results in the formation of a covalent intermediate between the enzyme and the DNA. This intermediate is displaced by water, resulting in cleavage of the scissile bond. Members of the phospholipase $\mathrm{D}$ family of enzymes also act by a two-step mechanism, in which a covalent phosphohistidine intermediate is formed (44-47). Both onestep (48-51) and two-step (16) mechanisms have been proposed for the AP endo mechanism 
of action. We were particularly interested in the chemical mechanism of AP endo in order to decipher the role of $\mathrm{Tyr}^{171}$ at the active site (16) and because of the physiological importance of this enzyme (52-54). Additionally, understanding the chemistry of an enzyme is an essential tool in the design of inhibitors, which in this case, could be used in concomitant therapy to increase the dose-effectiveness of cancer chemotherapeutics (52-56). Most chemotherapeutics act by damaging DNA with resulting damage often being repaired by DNA repair enzymes, such as AP endo. Therefore, if DNA repair can be inhibited in actively dividing cells, and the most actively dividing cells are cancer cells in most cases, then the dose of chemotherapeutic agents might be reduced without losing efficacy.

The Strauss laboratory published the first single turnover studies of AP endo and determined explicit binding and dissociation kinetics (11). We also have shown that both $\mathrm{His}^{309}$ and $\mathrm{Tyr}^{171}$ are intimately involved in catalysis by this enzyme $(15,16)$. Recently, Maher and Bloom published the first pre-steady state kinetic analysis of cleavage of a THF-containing substrate (57). They showed that the cleavage rate of AP endo is so fast as to be immeasurable using stopped-flow kinetics (minimally $850 \mathrm{~s}^{-1}$ ). The most important conclusion from the latter study (which investigated the WT as well as H309N and D210A mutants) is the fact that a slow step, which occurs after chemistry but before dissociation, limits the steady state incision activity to $2-10 \mathrm{~s}^{-1}$. The authors suggest a conformational change, which occurs after cleavage of the DNA, resulting in the following minimal enzymatic scheme:

$$
\mathrm{E}+\mathrm{S} \leftrightarrow[\mathrm{ES}] \rightarrow[\mathrm{EP}] \rightarrow[\mathrm{EP} *] \rightarrow \mathrm{E}+\mathrm{P}
$$

Based upon the results presented here, the most likely mechanism for AP endo on a THFcontaining substrate is an associative one-step hydrolytic mechanism. An analysis of the active site (Figure 6) implicates His ${ }^{309}$ as the general base generating the attacking nucleophile, with $\mathrm{Tyr}^{171}$ most likely acting as a guide to properly position the THF-containing substrate for catalysis. We suggest the following mechanism for human AP endo, when acting on a THFcontaining substrate: Binding of substrate DNA and the required divalent cation renders the enzyme catalytically "active". Although the divalent cation does not make direct contact with $\mathrm{Tyr}^{171}$, it does perturb the molecular environment of this residue (Mundle et al. manuscript in preparation). This perturbation, in turn, allows $\mathrm{Tyr}^{171}$ to properly position the AP site for cleavage. $\mathrm{Mg}^{2+}$, which is liganded by $\mathrm{Glu}^{96}$, makes contact with a nonbridging oxygen of the scissile phosphate, rendering it electropositive and open to attack, presumably by water. $\mathrm{His}^{309}$ generates the attacking nucleophile. Attack results in the formation of a pentavalent transition state, followed by expulsion of the 5' leaving group and cleavage of the phosphodiester bond.

In this study we expand upon evidence that AP endo cleaves the $R_{\mathrm{p}}$ but not the $S_{\mathrm{p}}$ stereoisomer of DNA phosphorothioate oligomers albeit slowly with respect to a phosphodiester substrate (14). This observation was important to the overall scheme of the work presented here. Since separation of the $R_{\mathrm{p}}$ and $S_{\mathrm{p}}$ diastereomers of the substrate DNA was not achieved, the AP endo reaction was performed on substrate which contained a 1:1 mixture of the two. In the $S_{\mathrm{p}}$ diastereomer of phosphorothioate DNA, sulfur occupies what would be the proS oxygen of a phosphodiester linkage, therefore the $S_{\mathrm{p}}$ diastereomer sterically prevents binding by the required divalent cation, $\mathrm{Mg}^{2+}$, which under normal circumstances makes contact with the nonbridging proS oxygen of the phosphodiester bond, ensuring that AP endo is only able to cleave the $R_{\mathrm{p}}$ containing substrate molecule. Here we show unequivocally that the mechanism of AP endo on a THF-containing substrate DNA proceeds by a one-step mechanism, which has always been shown to proceed with inversion of configuration at the scissile phosphate. 


\section{Supplementary Material}

Refer to Web version on PubMed Central for supplementary material.

\section{ABBREVIATIONS}

AP endo, apurinic/apyrimidinic endonuclease; AP, abasic; BER, base excision repair; dRP, deoxyribose phosphate; ESI-TOF MS, electrospray ionization-time of flight mass spectrometry; THF, tetrahydrofuran.

\section{LITERATURE CITED}

1. Evans AR, Limp-Foster M, Kelley MR. Going APE over ref-1. Mutat Res 2000;461:83-108. [PubMed: 11018583]

2. Strauss, PR.; O'Regan, NE. Abasic Site Repair in Higher Eukaryotes. In: Nickoloff, JA.; Hoekstra, MF., editors. DNA Damage and Repair. Totowa, NJ: Humana Press Inc.; 2001. p. 43-85.

3. Yajko DM, Weiss B. Mutations simultaneously affecting endonuclease II and exonuclease III in Escherichia coli. Proc Natl Acad Sci U S A 1975;72:688-692. [PubMed: 1091930]

4. Linsley WS, Penhoet EE, Linn S. Human endonuclease specific for apurinic/apyrimidinic sites in DNA. Partial purification and characterization of multiple forms from placenta. J Biol Chem 1977;252:12351242. [PubMed: 14146]

5. Mosbaugh DW, Linn S. Further characterization of human fibroblast apurinic/apyrimidinic DNA endonucleases. The definition of two mechanistic classes of enzyme. J Biol Chem 1980;255:1174311752. [PubMed: 6254980]

6. Rogers SG, Weiss B. Exonuclease III of Escherichia coli K-12, an AP endonuclease. Methods in Enzymology 1980;65:201-211. [PubMed: 6246343]

7. Robson CN, Hickson ID. Isolation of cDNA clones encoding a human apurinic/apyrimidinic endonuclease that corrects DNA repair and mutagenesis defects in E. coli xth (exonuclease III) mutants. Nucleic Acids Res 1991;19:5519-5523. [PubMed: 1719477]

8. Robson CN, Milne AM, Pappin DJ, Hickson ID. Isolation of cDNA clones encoding an enzyme from bovine cells that repairs oxidative DNA damage in vitro: homology with bacterial repair enzymes. Nucleic Acids Res 1991;19:1087-1092. [PubMed: 1708495]

9. Seki S, Akiyama K, Watanabe S, Hatsushika M, Ikeda S, Tsutsui K. cDNA and deduced amino acid sequence of a mouse DNA repair enzyme (APEX nuclease) with significant homology to Escherichia coli exonuclease III. J Biol Chem 1991;266:20797-20802. [PubMed: 1939131]

10. Seki S, Ikeda S, Watanabe S, Hatsushika M, Tsutsui K, Akiyama K, Zhang B. A mouse DNA repair enzyme (APEX nuclease) having exonuclease and apurinic/apyrimidinic endonuclease activities: purification and characterization. Biochimica et Biophysica Acta 1991;1079:57-64. [PubMed: 1716153]

11. Strauss PR, Beard WA, Patterson TA, Wilson SH. Substrate binding by human apurinic/apyrimidinic endonuclease indicates a Briggs-Haldane mechanism. J Biol Chem 1997;272:1302-1307. [PubMed: 8995436]

12. Slupphaug G, Eftedal I, Kavli B, Bharati S, Helle NM, Haug T, Levine DW, Krokan HE. Properties of a recombinant human uracil-DNA glycosylase from the UNG gene and evidence that UNG encodes the major uracil-DNA glycosylase. Biochemistry 1995;34:128-138. [PubMed: 7819187]

13. Erzberger JP, Barsky D, Scharer OD, Colvin ME, Wilson DM 3rd. Elements in abasic site recognition by the major human and Escherichia coli apurinic/apyrimidinic endonucleases. Nucleic Acids Res 1998;26:2771-2778. [PubMed: 9592167]

14. Wilson DM 3rd, Takeshita M, Grollman AP, Demple B. Incision activity of human apurinic endonuclease (Ape) at abasic site analogs in DNA. J Biol Chem 1995;270:16002-16007. [PubMed: 7608159]

15. Lucas JA, Masuda Y, Bennett RA, Strauss NS, Strauss PR. Single-turnover analysis of mutant human apurinic/apyrimidinic endonuclease. Biochemistry 1999;38:4958-4964. [PubMed: 10213597] 
16. Mundle ST, Fattal MH, Melo LF, Coriolan JD, O'Regan NE, Strauss PR. Novel role of tyrosine in catalysis by human AP endonuclease 1. DNA Repair (Amst) 2004;3:1447-1455. [PubMed: 15380100]

17. Summerton JE. Morpholino, siRNA, and S-DNA compared: impact of structure and mechanism of action on off-target effects and sequence specificity. Curr Top Med Chem 2007;7:651-660. [PubMed: 17430206]

18. Rocchi P, Jugpal P, So A, Sinneman S, Ettinger S, Fazli L, Nelson C, Gleave M. Small interference RNA targeting heat-shock protein 27 inhibits the growth of prostatic cell lines and induces apoptosis via caspase-3 activation in vitro. BJU International 2006;98:1082-1089. [PubMed: 16879439]

19. Foger F, Noonpakdee W, Loretz B, Joojuntr S, Salvenmoser W, Thaler M, Bernkop-Schnurch A. Inhibition of malarial topoisomerase II in Plasmodium falciparum by antisense nanoparticles. International Journal of Pharmaceutics 2006;319:139-146. [PubMed: 16713146]

20. Elliott SL, Brazier J, Cosstick R, Connolly BA. Mechanism of the Escherichia coli DNA T:Gmismatch endonuclease (Vsr protein) probed with thiophosphate-containing oligodeoxynucleotides. J Mol Biol 2005;353:692-703. [PubMed: 16188275]

21. Mizuuchi K, Nobbs TJ, Halford SE, Adzuma K, Qin J. A new method for determining the stereochemistry of DNA cleavage reactions: application to the SfiI and HpaII restriction endonucleases and to the MuA transposase. Biochemistry 1999;38:4640-4648. [PubMed: 10194386]

22. Sasnauskas G, Connolly BA, Halford SE, Siksnys V. Site-specific DNA transesterification catalyzed by a restriction enzyme. Proc Natl Acad Sci U S A 2007;104:2115-2120. [PubMed: 17267608]

23. Stivers JT, Jagadeesh GJ, Nawrot B, Stec WJ, Shuman S. Stereochemical outcome and kinetic effects of Rp-and Sp-phosphorothioate substitutions at the cleavage site of vaccinia type I DNA topoisomerase. Biochemistry 2000;39:5561-5572. [PubMed: 10820030]

24. Bogenhagen DF, Pinz KG. The action of DNA ligase at abasic sites in DNA. J Biol Chem 1998;273:7888-7893. [PubMed: 9525883]

25. Iyer RP, Egan W, Regan JB, Beaucage SL. 3H-1,2-benzodithiol-3-one 1,1-dioxide as an improved sulfurizing reagent in the solid-phase synthesis of oligodeoxyribonucleoside phosphorothioates. J Am Chem Soc 1990;112:1253-1254.

26. Subach FV, Müller S, Tashlitsky VN, Petrauskene OV, Gromova ES. The preparation of DNA duplexes containing internucleotide phosphorothioate groups in various positions of the recognition site for the EcoRII restriction endonuclease. Russian Journal of Bioorganic Chemistry 2003;29:566573.

27. Delaney JC, Smeester L, Wong C, Frick LE, Taghizadeh K, Wishnok JS, Drennan CL, Samson LD, Essigmann JM. AlkB reverses etheno DNA lesions caused by lipid oxidation in vitro and in vivo. Nature Structural \& Molecular Biology 2005;12:855-860.

28. Carey DC, Strauss PR. Human apurinic/apyrimidinic endonuclease is processive. Biochemistry 1999;38:16553-16560. [PubMed: 10600117]

29. Cieslak J, Ausin C, Chmielewski MK, Kauffman JS, Snyder J, Del-Grosso A, Beaucage SL. 31P NMR study of the desulfurization of oligonucleoside phosphorothioates effected by "aged" trichloroacetic acid solutions. The Journal of Organic Chemistry 2005;70:3303-3306. [PubMed: 15823001]

30. Xu Q, Barany G, Hammer RP, Musier-Forsyth K. Efficient introduction of phosphorothioates into RNA oligonucleotides by 3-ethoxy-1,2,4-dithiazoline-5-one (EDITH). Nucleic Acids Res 1996;24:3643-3644. [PubMed: 8836195]

31. Eckstein F. Nucleoside phosphorothioates. Annu Rev Biochem 1985;54:367-402. [PubMed: 2411211]

32. Knowles JR. Enzyme-catalyzed phosphoryl transfer reactions. Annu Rev Biochem 1980;49:877-919. [PubMed: 6250450]

33. Connolly BA, Eckstein F, Pingoud A. The stereochemical course of the restriction endonuclease EcoRI-catalyzed reaction. J Biol Chem 1984;259:10760-10763. [PubMed: 6088516]

34. Connolly BA, Potter BV, Eckstein F, Pingoud A, Grotjahn L. Synthesis and characterization of an octanucleotide containing the EcoRI recognition sequence with a phosphorothioate group at the cleavage site. Biochemistry 1984;23:3443-3453. [PubMed: 6087894] 
35. Grasby JA, Connolly BA. Stereochemical outcome of the hydrolysis reaction catalyzed by the EcoRV restriction endonuclease. Biochemistry 1992;31:7855-7861. [PubMed: 1510972]

36. Jeltsch A, Alves J, Wolfes H, Maass G, Pingoud A. Substrate-assisted catalysis in the cleavage of DNA by the EcoRI and EcoRV restriction enzymes. Proc Natl Acad Sci U S A 1993;90:8499-8503. [PubMed: 8378323]

37. Koziolkiewicz M, Stec WJ. Application of phosphate-backbone-modified oligonucleotides in the studies on EcoRI endonuclease mechanism of action. Biochemistry 1992;31:9460-9466. [PubMed: 1390728]

38. Nobbs TJ, Williams SA, Connolly BA, Halford SE. Phosphorothioate substrates for the SfiI restriction endonuclease. Biological Chemistry 1998;379:599-604. [PubMed: 9628364]

39. Thorogood H, Grasby JA, Connolly BA. Influence of the phosphate backbone on the recognition and hydrolysis of DNA by the EcoRV restriction endonuclease. A study using oligodeoxynucleotide phosphorothioates. J Biol Chem 1996;271:8855-8862. [PubMed: 8621526]

40. Dahlberg ME, Benkovic SJ. Kinetic mechanism of DNA polymerase I (Klenow fragment): identification of a second conformational change and evaluation of the internal equilibrium constant. Biochemistry 1991;30:4835-4843. [PubMed: 1645180]

41. El Dirani-Diab R, Sarih-Cottin L, Delord B, Dumon B, Moreau S, Toulme JJ, Fleury H, Litvak S. Phosphorothioate oligonucleotides derived from human immunodeficiency virus type 1 (HIV-1) primer tRNALys 3 are strong inhibitors of HIV-1 reverse transcriptase and arrest viral replication in infected cells. Antimicrobial Agents and Chemotherapy 1997;41:2141-2148. [PubMed: 9333039]

42. Kaushik N, Rege N, Yadav PN, Sarafianos SG, Modak MJ, Pandey VN. Biochemical analysis of catalytically crucial aspartate mutants of human immunodeficiency virus type 1 reverse transcriptase. Biochemistry 1996;35:11536-11546. [PubMed: 8794733]

43. Radzio J, Sluis-Cremer N. Stereo-selectivity of HIV-1 reverse transcriptase toward isomers of thymidine-5'-O-1-thiotriphosphate. Protein Sci 2005;14:1929-1933. [PubMed: 15937285]

44. Gottlin EB, Rudolph AE, Zhao Y, Matthews HR, Dixon JE. Catalytic mechanism of the phospholipase D superfamily proceeds via a covalent phosphohistidine intermediate. Proc Natl Acad Sci U S A 1998;95:9202-9207. [PubMed: 9689058]

45. Interthal H, Pouliot JJ, Champoux JJ. The tyrosyl-DNA phosphodiesterase Tdp1 is a member of the phospholipase D superfamily. Proc Natl Acad Sci U S A 2001;98:12009-12014. [PubMed: 11572945]

46. Ponting CP, Kerr ID. A novel family of phospholipase D homologues that includes phospholipid synthases and putative endonucleases: identification of duplicated repeats and potential active site residues. Protein Sci 1996;5:914-922. [PubMed: 8732763]

47. Waite M. The PLD superfamily: insights into catalysis. Biochimica et Biophysica Acta 1999;1439:187-197. [PubMed: 10425395]

48. Beernink PT, Segelke BW, Hadi MZ, Erzberger JP, Wilson DM 3rd, Rupp B. Two divalent metal ions in the active site of a new crystal form of human apurinic/apyrimidinic endonuclease, Ape1: implications for the catalytic mechanism. J Mol Biol 2001;307:1023-1034. [PubMed: 11286553]

49. Gorman MA, Morera S, Rothwell DG, de La Fortelle E, Mol CD, Tainer JA, Hickson ID, Freemont PS. The crystal structure of the human DNA repair endonuclease HAP1 suggests the recognition of extra-helical deoxyribose at DNA abasic sites. EMBO J 1997;16:6548-6558. [PubMed: 9351835]

50. Mol CD, Izumi T, Mitra S, Tainer JA. DNA-bound structures and mutants reveal abasic DNA binding by APE1 and DNA repair coordination [corrected]. Nature 2000;403:451-456. [PubMed: 10667800]

51. Oezguen N, Schein CH, Peddi SR, Power TD, Izumi T, Braun W. A "moving metal mechanism" for substrate cleavage by the DNA repair endonuclease APE-1. Proteins 2007;68:313-323. [PubMed: 17427952]

52. Fishel ML, Kelley MR. The DNA base excision repair protein Ape1/Ref-1 as a therapeutic and chemopreventive target. Molecular Aspects of Medicine 2007;28:375-395. [PubMed: 17560642]

53. Luo M, Kelley MR. Inhibition of the human apurinic/apyrimidinic endonuclease (APE1) repair activity and sensitization of breast cancer cells to DNA alkylating agents with lucanthone. Anticancer Research 2004;24:2127-2134. [PubMed: 15330152] 
54. Robertson KA, Bullock HA, Xu Y, Tritt R, Zimmerman E, Ulbright TM, Foster RS, Einhorn LH, Kelley MR. Altered expression of Ape1/ref-1 in germ cell tumors and overexpression in NT2 cells confers resistance to bleomycin and radiation. Cancer Res 2001;61:2220-2225. [PubMed: 11280790]

55. Fahrig R, Quietzsch D, Heinrich JC, Heinemann V, Boeck S, Schmid RM, Praha C, Liebert A, Sonntag D, Krupitza G, Hanel M. RP101 improves the efficacy of chemotherapy in pancreas carcinoma cell lines and pancreatic cancer patients. Anti-Cancer Drugs 2006;17:1045-1056. [PubMed: 17001178]

56. Yang ZZ, Chen XH, Wang D. Experimental study enhancing the chemosensitivity of multiple myeloma to melphalan by using a tissue-specific APE1-silencing RNA expression vector. Clinical Lymphoma \& Myeloma 2007;7:296-304. [PubMed: 17324338]

57. Maher RL, Bloom LB. Pre-steady-state kinetic characterization of the AP endonuclease activity of human AP endonuclease 1. J Biol Chem 2007;282:30577-30585. [PubMed: 17724035]

58. Engler, MJ.; Richardson, CC. The Enzymes. In: Boyer, PD., editor. The Enzymes. New York, NY: Academic Press; 1982. p. 3-29.

59. Sayle RA, Milner-White EJ. RASMOL: biomolecular graphics for all. Trends in Biochemical Sciences 1995;20:374. [PubMed: 7482707] 

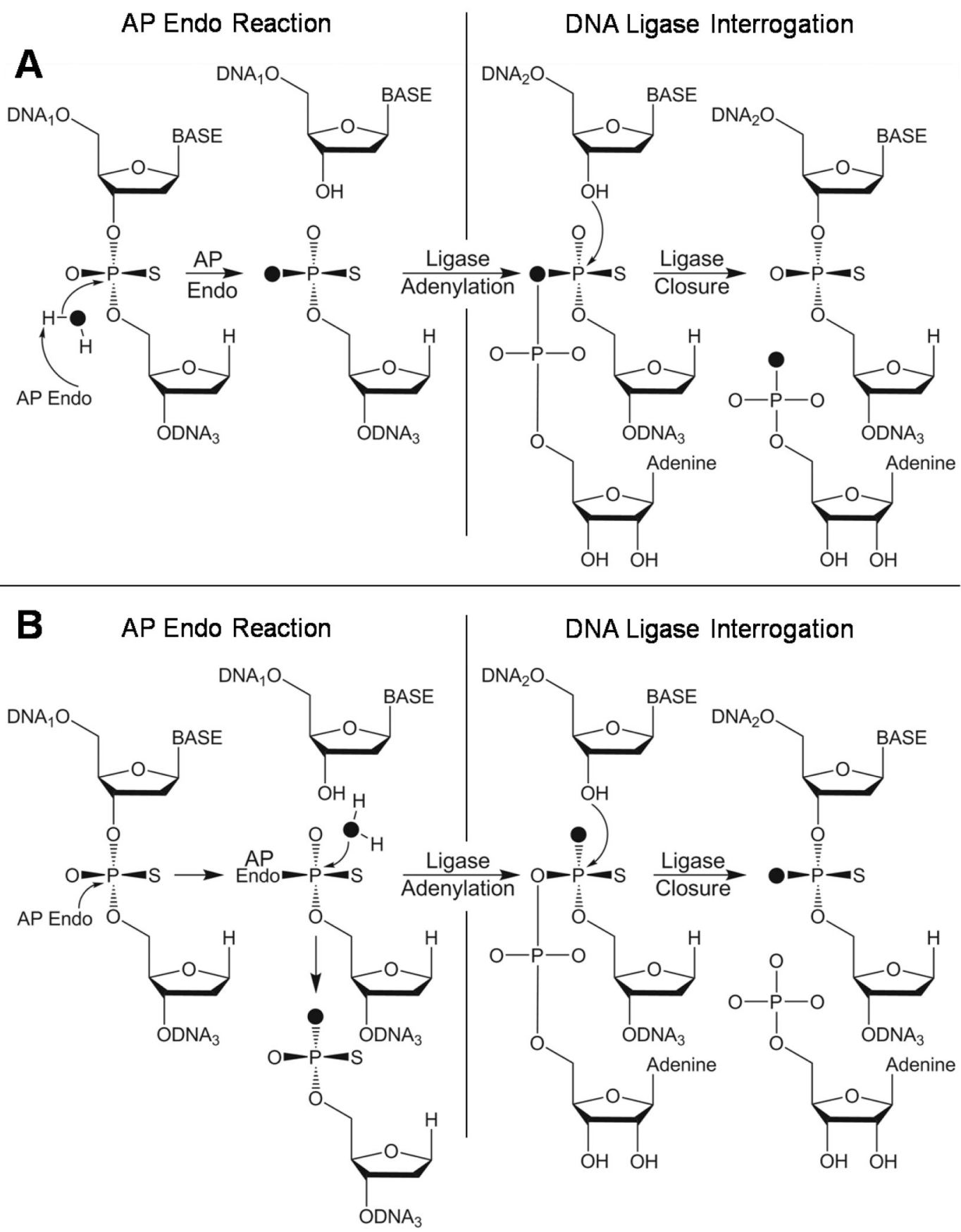

Figure 1. Stereochemical course of the reactions described in the text

Panel A shows the fate of ${ }^{18} \mathrm{O}(\bullet)$ in a one-step hydrolytic mechanism. Panel B shows the fate of ${ }^{18} \mathrm{O}(\bullet)$ in a two-step hydrolytic mechanism. Since it is known that AP endonuclease only appreciably cleaves the $R_{p}$ diastereomer, the reaction is depicted using the $R_{p}$ stereoisomer as the starting material. In a one-step hydrolysis, ${ }^{18} \mathrm{O}$ is transferred to the proR oxygen of the cleaved oligomer product, but is then lost to AMP during the stereospecific T4 DNA ligase reaction (58). In a two-step hydrolysis, the heavy oxygen is transferred to the proS oxygen of the cleaved product DNA, and is retained during the stereospecific T4 DNA ligase reaction. Bond order and charge about the phosphorous were omitted for stereochemical clarity. 


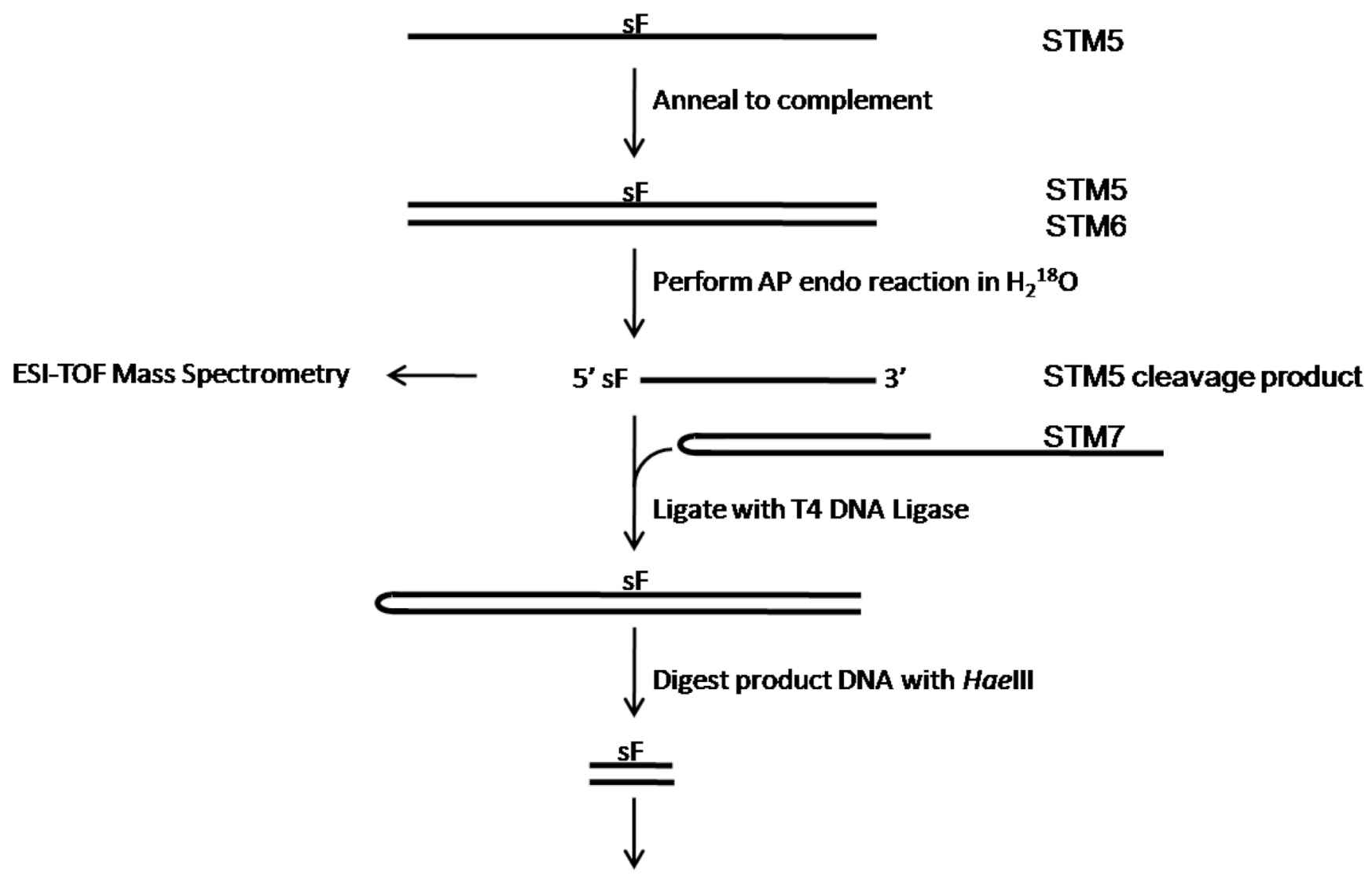

ESI-TOF Mass Spectrometry

Figure 2. Schematic representation of the phosphorothioate experiment to determine the AP endo reaction mechanism

In the figure, $\mathrm{sF}$ represents the tetrahydrofuran AP site analog containing a 5' phoshorothioate linkage, and analysis of ESI-TOF mass spectra was performed using the extracted ions of the modified single-stranded DNA. 


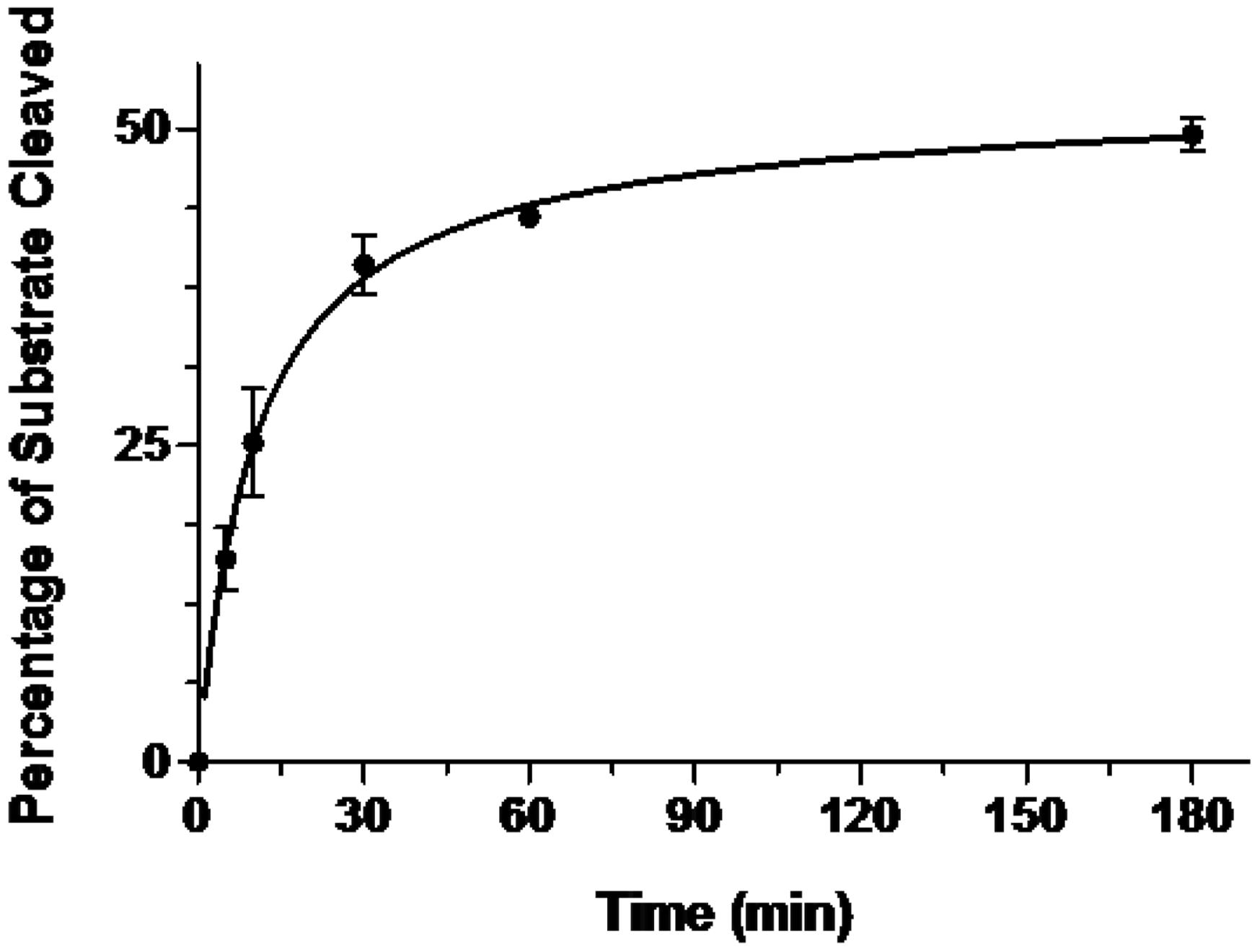

Figure 3. Time course of the AP endo reaction

The ability of AP endo to cleave the constructed substrate DNA was examined using radiolabeled substrate DNA and conditions as described in the text. These data are the average of two independent experiments, each point being determined in duplicate in each experiment. 


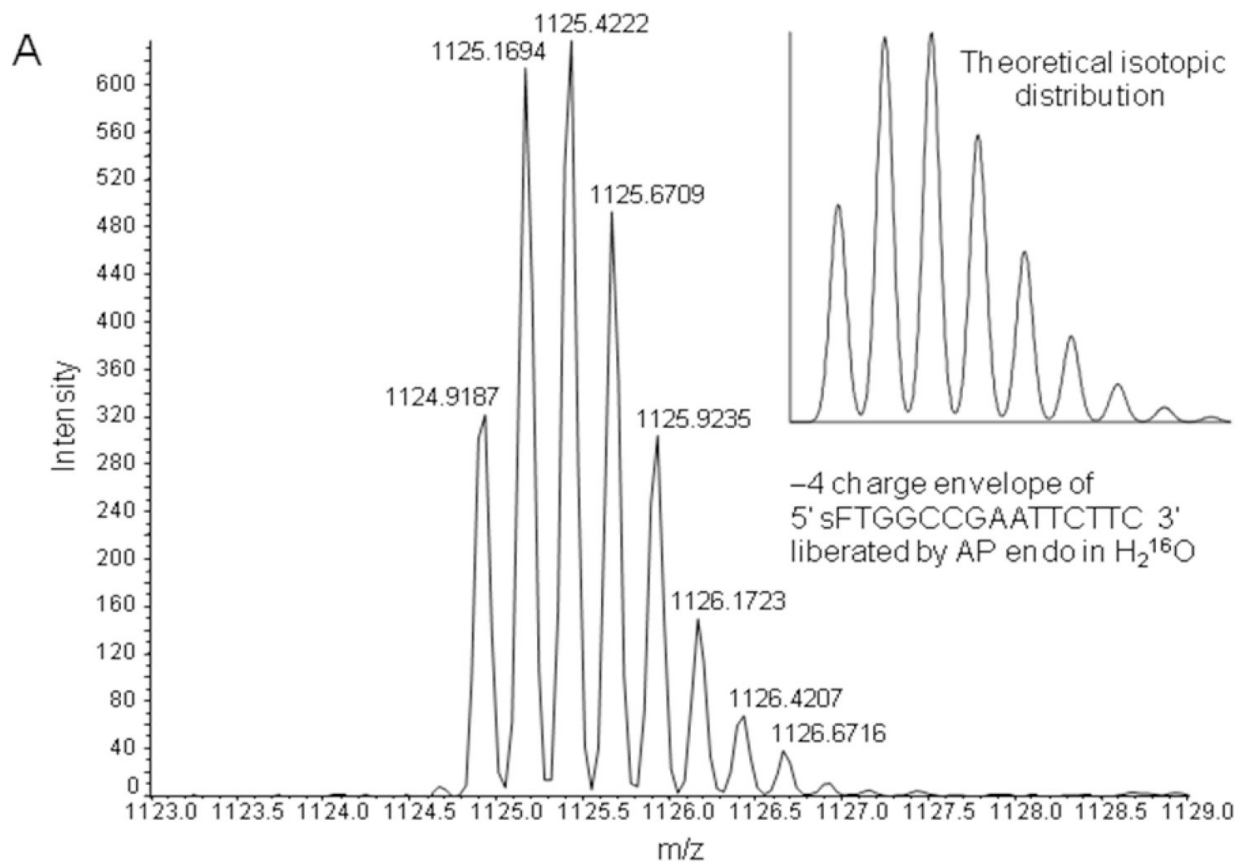

B

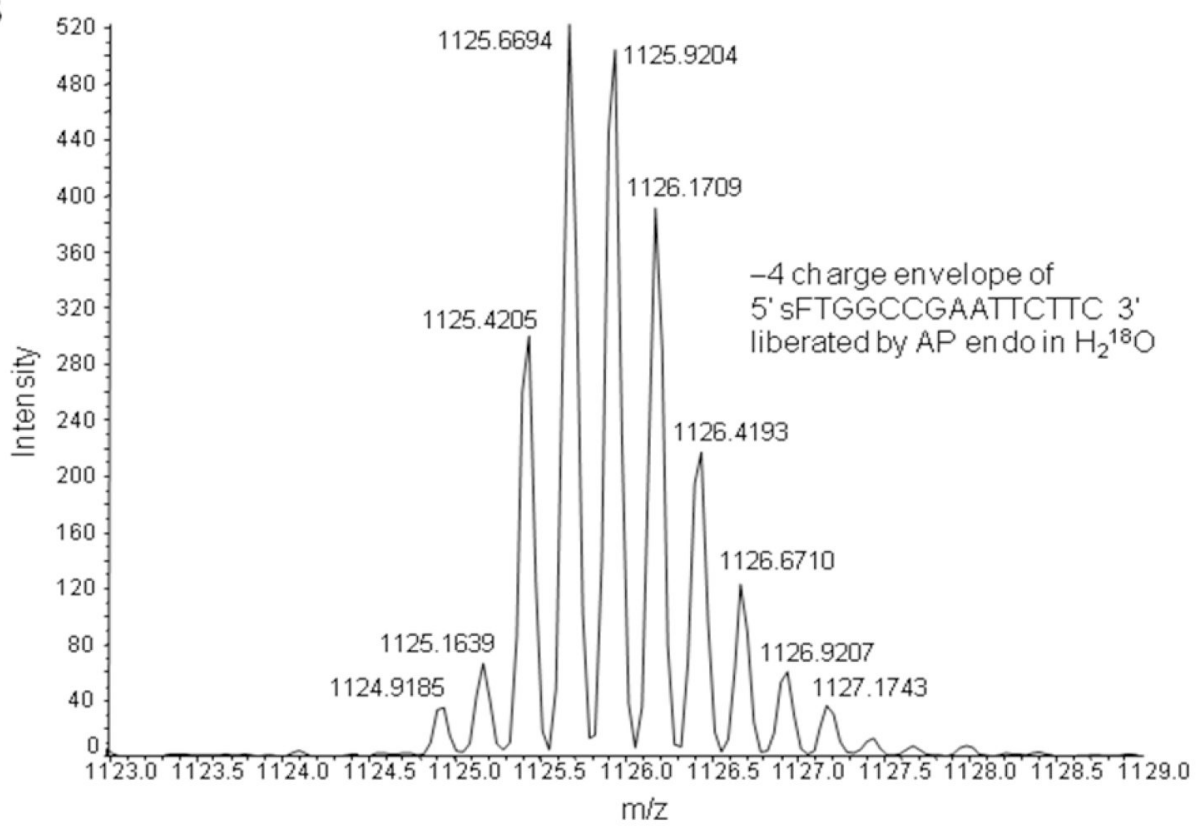

Figure 4. ESI-TOF MS analysis of the AP endonuclease reaction product performed in $\mathrm{H}_{2} \mathrm{O}$ and $\mathrm{H}_{2} \mathbf{1 8}_{\mathbf{O}}$

ESI-TOF MS was performed as described in the Methods. Panel A shows the results obtained when the AP endo reaction was performed in $\mathrm{H}_{2} \mathrm{O}$, as well as the theoretical isotopic distribution. Panel B shows the results of the AP endo reaction performed in $\mathrm{H}_{2}{ }^{18} \mathrm{O}$. Extraction of ions between 1123 and $1127(\mathrm{~m} / \mathrm{z})$ revealed -4 envelopes containing monoisotopic $\left(100 \%{ }^{12} \mathrm{C}\right.$ ) values of 1124.919 (reaction in $\mathrm{H}_{2} \mathrm{O}$ ) and 1125.421 (reaction in $\mathrm{H}_{2}{ }^{18} \mathrm{O}$ ) for the single-stranded $15 \mathrm{mers}$. The theoretical isotopic distribution for 5', sFTGGCCGAATTCTTC 3 ' is shown in the inset. 

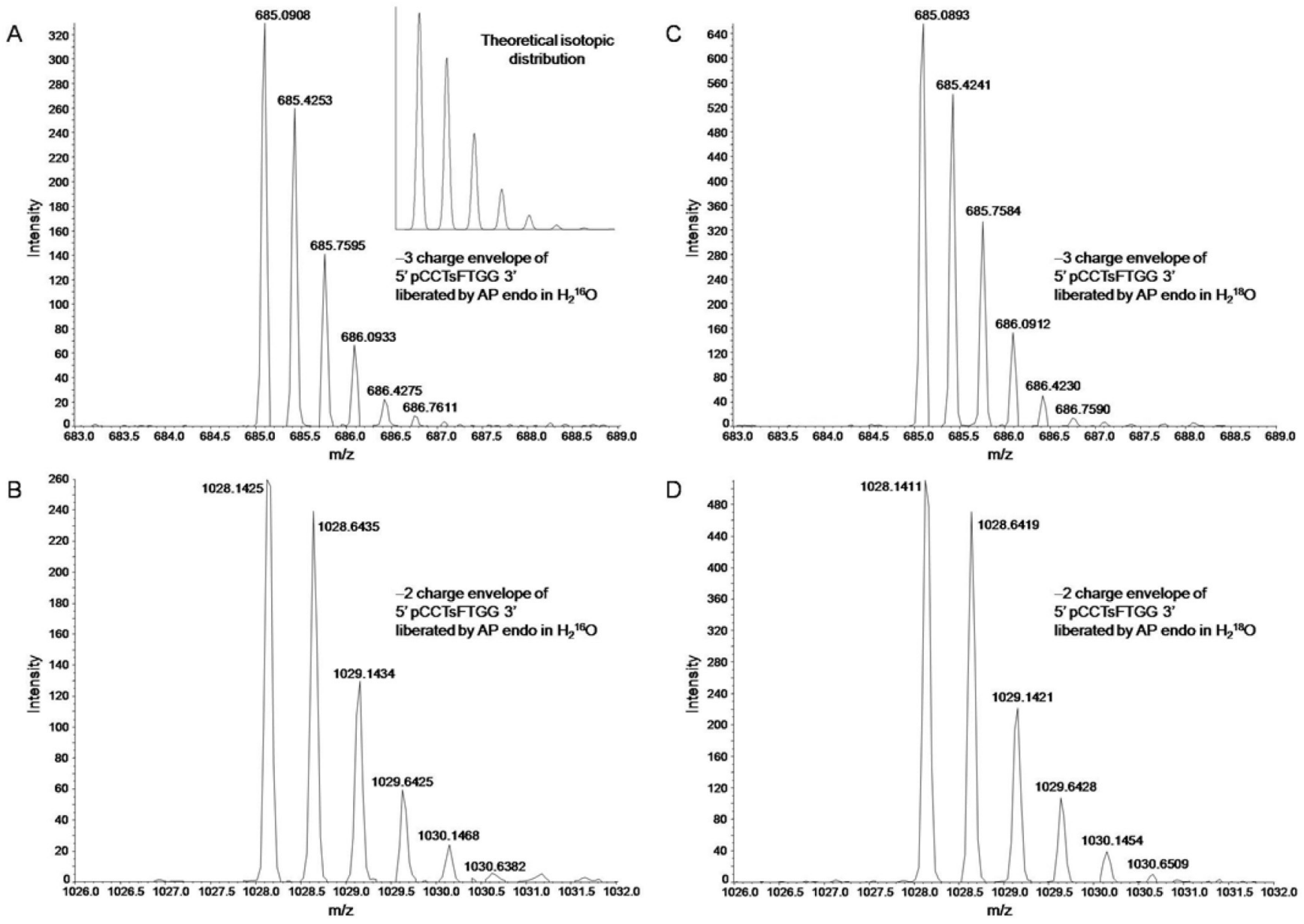

Figure 5. ESI-TOF MS analysis of the ligation/HaeIII reaction product performed in $\mathrm{H}_{2} \mathrm{O}$ ESI-TOF MS was performed as described in the text. Mass to charge ratios of the singlestranded 7 mer were obtained for the $-3,685.091$ (A) and -2, 1028.143 (B) charge states. The theoretical isotopic distribution for 5' pCCTsFTGG 3' (any charge state) is shown in the inset. Mass to charge ratios of the single-stranded 7mer product DNA were similar to those obtained when the AP endo reaction was performed in $\mathrm{H}_{2} \mathrm{O}$ for the $-3,685.089$ (C) and $-2,1028.141$ (D) charge states. This result indicates that the reaction proceeds by a one step mechanism. 


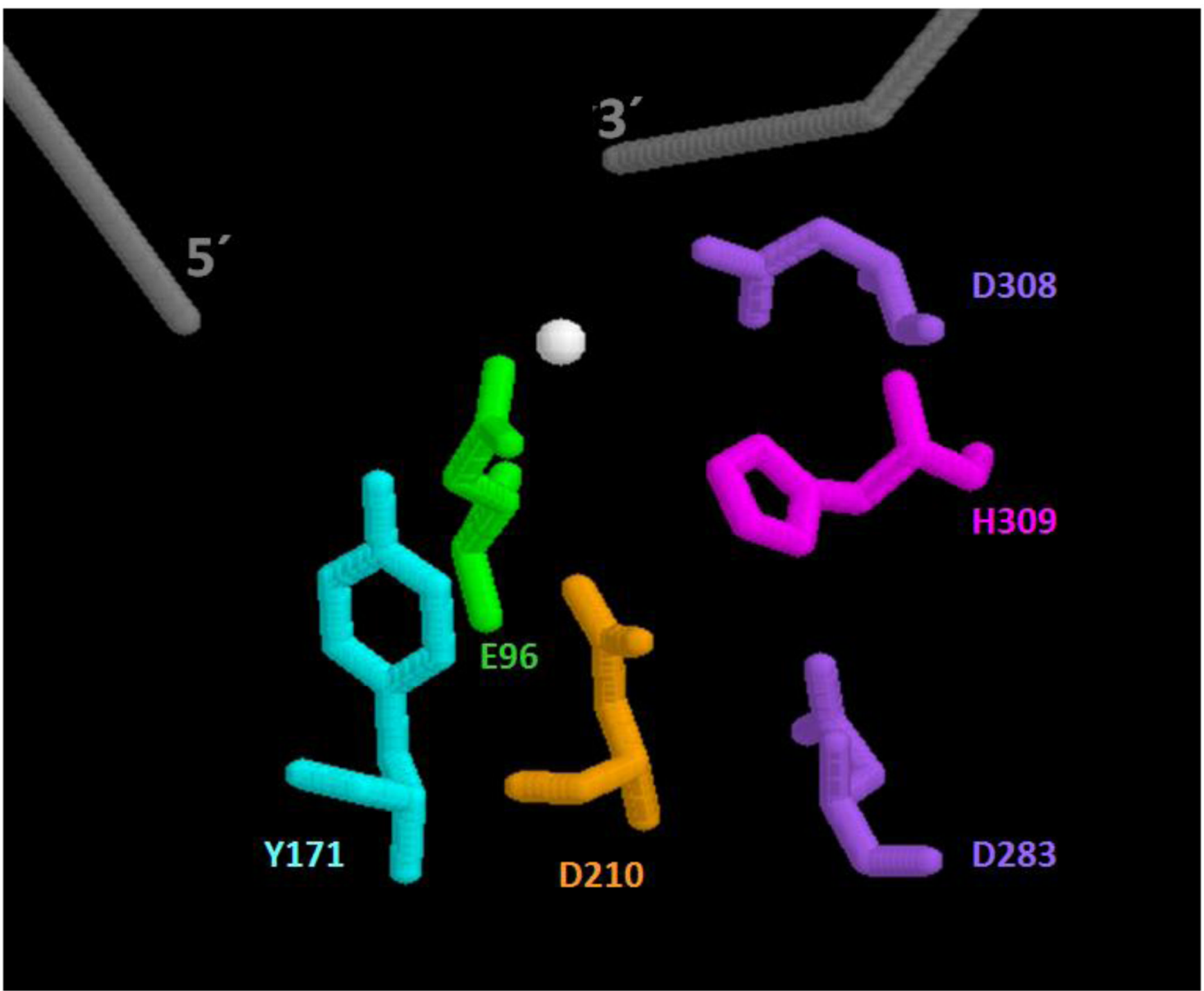

Figure 6. Stereo view showing the active site residues of human AP endo in complex with cleaved product DNA (50)

The proposed roles of active site residues, His $^{309}$ (magenta), Tyr $^{171}$ (cyan), and Glu ${ }^{96}$ (green), are described in the text. Glu ${ }^{96}$ is shown bound to the divalent cation $\left(\mathrm{Mn}^{2+}\right)$ (white), with which the structure was co-crystallized. Others (50) have proposed that $\mathrm{Asp}^{210}$ (orange) may serve to generate the attacking nucleophile. Lucas, et al. have shown that based on kinetic studies, both $\mathrm{Asp}^{283}$ and $\mathrm{Asp}^{308}$ (purple), which flank the active site histidine, are equally involved in maintaining the conformation of the active site (15). This figure was created using the RasMol molecular viewing program (59). 